\title{
Production of tailor-made enzymes to facilitate lipid extraction from the oleaginous yeast Schwanniomyces occidentalis
}

\author{
Ruud Heshof ' (D), Bram Visscher, Eric van de Zilver, Rick van de Vondervoort, Femke van Keulen, \\ Roy J. B. M. Delahaije and Richèle D. Wind
}

\begin{abstract}
Due to the depletion of fossil fuel resources and concern about increasing atmospheric $\mathrm{CO}_{2}$ levels, the production of microbial oil as source for energy and chemicals is considered as a sustainable alternative. A promising candidate strain for the production of microbial oil is the oleaginous yeast Schwanniomyces occidentalis CBS 2864. To compete with fossil resources, cultivation and processing of $S$. occidentalis requires improvement. Currently, different cell wall disruption techniques based on mechanical, chemical, physiological, and biological methods are being investigated using a variety of oil producing yeasts and microalgae. Most of these techniques are not suitable for upscaling because they are technically or energetically unfavorable. Therefore, new techniques have to be developed to overcome this challenge. Here, we demonstrate an effective mild enzymatic approach for cell disruption to facilitate lipid extraction from the oleaginous yeast S. occidentalis. Most oil was released by applying $187 \mathrm{mg} \mathrm{L}^{-1}$ tailor-made enzymes from Trichoderma harzianum CBS 146429 against the yeast cell wall of S. occidentalis at pH 5.0 and $40^{\circ} \mathrm{C}$ with $4 \mathrm{~h}$ of incubation time after applying $1 \mathrm{M} \mathrm{NaOH}$ as a pretreatment step.
\end{abstract}

Keywords: Trichoderma harzianum, Lytic enzymes, Microbial oil, Fermentation, Disruption

\section{Introduction}

Due to the expanding biobased economy, the interest in microbial oil is increasing (Athenaki et al. 2018; Sitepu et al. 2014a, b). The possibility of economically feasible bio-oil production is being investigated in algae, yeasts, and filamentous fungi (Remmers et al. 2017; Hao et al. 2016; Sitepu et al. 2014b; Ageitos et al. 2011). However, an economically viable production process will require improvements to oil yield through optimization of cultivation and processing, as well as isolation of multiple coproducts in a biorefinery setup, indicating the need for mild downstream processing techniques. Efficient extraction of these oils is one of the bottlenecks in ensuring that the use of microbial oil is economically viable (Dong

\footnotetext{
*Correspondence: rheshof@hotmail.com

HAN BioCentre, HAN University of Applied Sciences, Laan van Scheut 2, 6525 EM Nijmegen, the Netherlands
}

et al. 2016; Ghasemi Naghdi et al. 2016). Oleaginous microorganisms can accumulate more than $20 \%(\mathrm{w} / \mathrm{w})$ of their total biomass as lipids and are interesting candidates for industrial upscaling (Papanikolaou and Aggelis 2011). One of these oleaginous yeasts is Schwanniomyces occidentalis, which is capable of using a broad spectrum of C5 and C6 sugars for the production of microbial oil, mainly as oleic acid (Lamers et al. 2016). In addition, $S$. occidentalis is able to tolerate high concentrations of lignocellulosic hydrolysate inhibitors making it a suitable candidate for growth on renewable lignocellulosic materials (Sitepu et al. 2014a).

Multiple methods have been developed to disrupt the cell wall of oleaginous yeasts and are mainly categorized as chemical, mechanical, physical, and biological methods. These methods can be used on dry or wet biomass, but wet biomass is preferred since it eliminates the costly drying treatment of biomass (Dong et al. 2016). Currently 
mechanical high-pressure homogenization protocols are used in industry (Athenaki et al. 2018). However, the use of biological methods to disrupt cell walls is a promising technique due to possible prevention of thermal degradation of lipids (Dong et al. 2016). A possible biological technique is the use of enzymes. Enzyme mixtures used for the degradation of fungal cell walls mainly consist of glucanases, chitinases, $N$-acetyl- $\beta$-D-glucosaminidases, and proteases, which are commonly found in mycoparasites such as Trichoderma sp. (Fan et al. 2014; Yang et al. 2013; Silva et al. 2004; de las Mercedes Dana et al. 2001; Noronha and Ulhoa 2000). Trichoderma is therefore often used as a biological control agent in agriculture and in the preparation of fungal protoplasts (Elad et al. 1982). Mycoparasites are grouped in two categories: biotrophic and necrotrophic mycoparasites (Qualhato et al. 2013; Gruber and Seidl-Seiboth 2012). In biotrophic mycoparasitism, multiple organisms benefit from the nutrients obtained at the expense of a target organism, while in necrotrophic mycoparasitism the organism invades and destroys other cells and feeds on the resulting nutrients (Vos et al. 2015; Atanasova et al. 2013). Trichoderma sp. are categorized as necrotrophic mycoparasites (Mukherjee et al. 2012). Transcriptomic analysis for Trichoderma harzianum and Trichoderma atroviride infecting different fungi have revealed that fungal antagonism is a complex system in which many genes are involved related to mycoparasitism (Steindorff et al. 2014; Druzhinina et al. 2011; Reithner et al. 2011; Seidl et al. 2009). These genes are potentially coding for enzymes that are able to disrupt cell walls in yeast.

Biological methods have proven to be successful in the extraction of microbial oil from the yeast Rhodosporidium toruloides (Jin et al. 2012). However, a drawback is a thermal pretreatment step required for the yeast in order to weaken the fungal cell wall. In this study we present a production method for tailor-made enzymes (TMEs) that are capable of degrading the cell wall of the oleaginous yeast $S$. occidentalis after a non-thermal pretreatment step. After a $\mathrm{NaOH}$ pretreatment of the $S$. occidentalis cells the TMEs can be directly used from the cultivation to disrupt the cell wall.

\section{Materials and methods}

\section{Strains and culturing}

In this study, the strains S. occidentalis CBS 2864 and T. harzianum CBS 146429 were used. Precultures of $S$. occidentalis were grown at $30^{\circ} \mathrm{C}$ in $100 \mathrm{~mL}$ yeast-extract peptone dextrose (YPD) medium $\left(10 \mathrm{~g} \mathrm{~L}^{-1}\right.$ yeast extract (Gistex ${ }^{\circledR}$ LS Powder, DSM, the Netherlands), $20 \mathrm{~g} \mathrm{~L}^{-1}$ peptone (Casein Peptone Plus, Organo Technie, France), $40 \mathrm{~g} \mathrm{~L}^{-1}$ glucose monohydrate) using $500 \mathrm{~mL}$ shake flasks. For solid plates, an agar solution of $15 \mathrm{~g} \mathrm{~L}^{-1}$ was added. The carbon and nitrogen source were sterilized $\left(121{ }^{\circ} \mathrm{C} / 20 \mathrm{~min}\right.$ ) separately to prevent Maillard reactions. A spore solution of $1 \cdot 10^{8}$ spores $\mathrm{mL}^{-1}$ of $T$. harzianum was added to $100 \mathrm{~mL}$ potato dextrose broth (CP74.2, Carlroth, the Netherlands) and grown in a $500 \mathrm{~mL}$ baffled Erlenmeyer flask in a shaker (New Brunswick ${ }^{\mathrm{TM}}$ Innova $^{\circledR}$ 40, Eppendorf, the Netherlands) for $24 \mathrm{~h}$ at $150 \mathrm{rpm}$ and $30{ }^{\circ} \mathrm{C}$.

\section{Bioreactor cultivation \\ Bioreactor parameters and setup}

Precultures of $S$. occidentalis and T. harzianum were inoculated in $7 \mathrm{~L}$ vessels in a double continuous cultivation setup (Fig. 1). For all the bioreactor experiments BioFlo 115 controllers were used (Eppendorf, the Netherlands). The parameters used for the bioreactor cultivations are shown Table 1 . The liquid volume in the $T$. harzianum bioreactor was kept constant at $3.5 \mathrm{~L}$ using a Watson-Marlow $120 \mathrm{~S}$ peristaltic pump (Thermo Fisher Scientific, the Netherlands). The overflow was pumped towards a $4{ }^{\circ} \mathrm{C}$ water-cooled bottle to prevent sporulation of the T. harzianum biomass. After a cultivation time of $187 \mathrm{~h}$, the cultivation was terminated.

\section{Batch and fed-batch medium}

S. occidentalis was first grown in a batch phase using the following medium: $20 \mathrm{~g} \mathrm{~L}^{-1}$ glucose monohydrate, $10 \mathrm{~g}$ $\mathrm{L}^{-1}$ yeast extract (Gistex ${ }^{\circledR}$ LS Powder, DSM, the Netherlands), $20 \mathrm{~g} \mathrm{~L}^{-1}$ peptone (Casein Peptone Plus, Organo Technie, France) and tap water to a total of $5 \mathrm{~kg}$. After the batch phase, $S$. occidentalis was grown continuously using a feed of 2 L YPD medium at a feed rate of $4 \mathrm{~mL} \mathrm{~h}^{-1}$. T. harzianum was first grown in a batch phase using medium in which carbon sources, nitrogen sources, and minerals were sterilized $\left(121^{\circ} \mathrm{C} / 20 \mathrm{~min}\right)$ separately to avoid Maillard reactions and precipitation. A carbon source of $12 \mathrm{~g} \mathrm{~L}^{-1}$ glucose monohydrate was prepared in $2 \mathrm{~L}$ of demi water. A nitrogen source of $5.6 \mathrm{~g} \mathrm{~L}^{-1}$ yeast extract (Gistex ${ }^{\circledR}$ LS Powder, DSM, the Netherlands), $4 \mathrm{~g} \mathrm{~L}^{-1}$ peptone (Casein Peptone Plus, Organo Technie, France) and $1.2 \mathrm{~g} \mathrm{~L}^{-1}$ urea was prepared in $500 \mathrm{~mL}$ of demi water. After sterilization the following stock solutions were added to the bioreactor: $12 \mathrm{~mL}$ of $0.2 \mu \mathrm{m}$ filter-sterilized spore elements $\left(7.20 \mathrm{~g} \mathrm{~L}^{-1} \mathrm{MnCl}_{2} \cdot 4 \mathrm{H}_{2} \mathrm{O}\right.$, $8.82 \mathrm{~g} \mathrm{~L}^{-1} \mathrm{ZnSO}_{4} \cdot 7 \mathrm{H}_{2} \mathrm{O}$, and $1.25 \mathrm{~g} \mathrm{~L}^{-1} \mathrm{CuSO}_{4} \cdot 5 \mathrm{H}_{2} \mathrm{O}$ ), $12 \mathrm{~mL}$ of a $0.2 \mu \mathrm{m}$ filter-sterilized $10 \mathrm{~g} \mathrm{~L}^{-1} \mathrm{FeCl}_{3} \cdot 6 \mathrm{H}_{2} \mathrm{O}$ solution, $25 \mathrm{~mL}$ of autoclaved $3.60 \mathrm{~g} \mathrm{~L}^{-1} \mathrm{MgSO}_{4} \cdot 7 \mathrm{H}_{2} \mathrm{O}$, $25 \mathrm{~mL}$ of autoclaved $4.80 \mathrm{~g} \mathrm{~L}^{-1} \mathrm{CaCl}_{2} \cdot 2 \mathrm{H}_{2} \mathrm{O}$, and $250 \mathrm{~mL}$ of $1 \mathrm{M} \mathrm{K}_{2} \mathrm{HPO}_{4}$ buffer that was set to $\mathrm{pH} 5.8$ using $1 \mathrm{M}$ of $\mathrm{NaH}_{2} \mathrm{PO}_{4}$. Feeding of $T$. harzianum with $S$. occidentalis was initiated after $19 \mathrm{~h}$ at a pump speed of $20 \mathrm{~mL} \mathrm{~h}^{-1}$. After the $187 \mathrm{~h}$ of total cultivation time of T. harzianum, the biomass was separated from the broth by centrifuging 


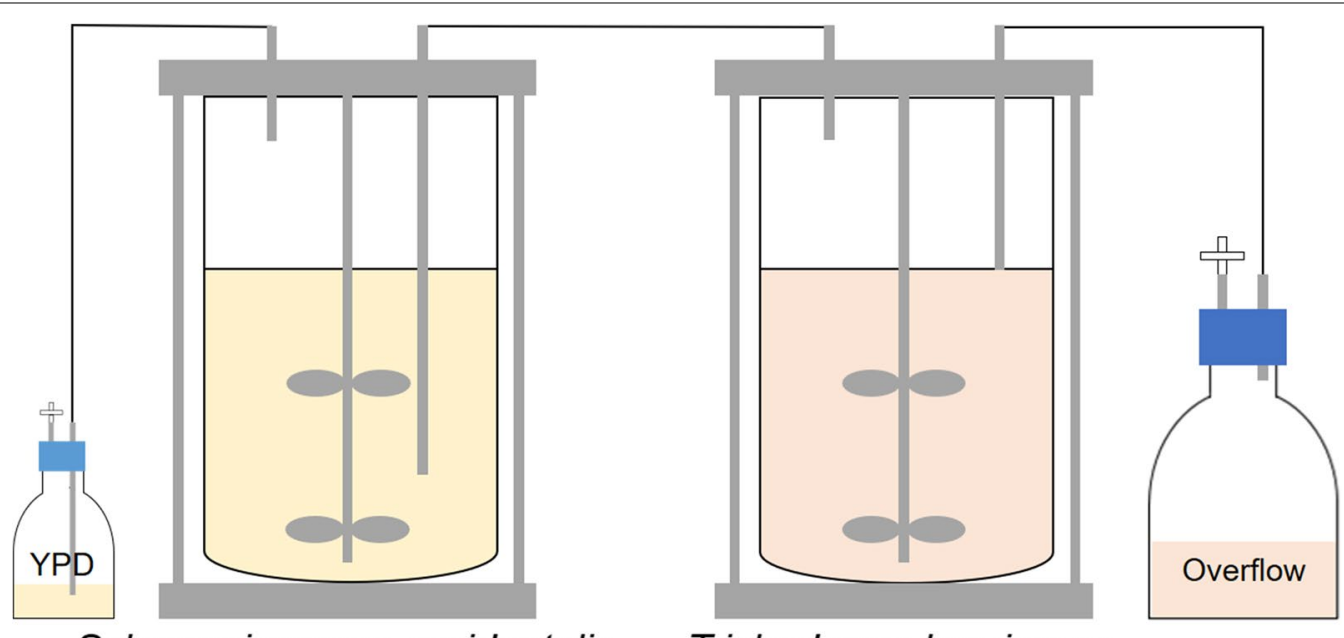

\section{Schwanniomyces occidentalis Trichoderma harzianum}

Fig. 1 Experimental setup of the double continuous cultivation of the TMEs. Schematic overview of the production of tailor-made enzymes (TMEs) using a double continuous fermentation. In the first bioreactor Schwanniomyces occidentalis is continuously grown on YPD medium. In the second bioreactor Trichoderma harzianum is fed with living S. occidentalis. In this way T. harzianum will start producing TMEs against S. occidentalis. At the end of the cultivation, the T. harzianum broth is harvested and the supernatant separated from the biomass. This supernatant is used as the TME cocktail in further experiments

Table 1 Parameters used for the bioreactor cultivations of Schwanniomyces occidentalis and Trichoderma harzianum

\begin{tabular}{|c|c|c|}
\hline Parameter & S. occidentalis & T. harzianum \\
\hline Agitation (rpm) & $300-1200$ & $300-1200$ \\
\hline Dissolved oxygen control (\%) & 20_-agitation cascade controlled & 20_-agitation cascade controlled \\
\hline Temperature $\left({ }^{\circ} \mathrm{C}\right)$ & 30 & 30 \\
\hline $\mathrm{pH}$ & $5.5 \pm 0.1$ & $4.9 \pm 0.1$ \\
\hline Acid & $6 \mathrm{M} \mathrm{H}_{3} \mathrm{PO}_{4}$-pump speed $20 \%$ & $6 \mathrm{M} \mathrm{H}_{3} \mathrm{PO}_{4}$-pump speed $20 \%$ \\
\hline Base & $6 \mathrm{M} \mathrm{NaOH}$-pump speed $20 \%$ & $6 \mathrm{M} \mathrm{NaOH}$-pump speed $20 \%$ \\
\hline Feed & YPD & S. occidentalis_-pump speed $10 \%$ \\
\hline Gasflow (vvm) & 0.5 - pressurized air & 0.5 - pressurized air \\
\hline Cultivation duration batch phase & 18-22 h-until DO and pH started rising & 36-40 h-until DO and pH started rising \\
\hline Cultivation duration fed-batch phase & 160-180 h total cultivation time & $\sim 140-180 \mathrm{~h}$ total cultivation time \\
\hline
\end{tabular}

for $30 \mathrm{~min}$ at $17,700 \times g$ at $4{ }^{\circ} \mathrm{C}$. The broth was stored at $-20{ }^{\circ} \mathrm{C}$ in aliquots of $500 \mathrm{~mL}$.

\section{Sampling}

Samples of $5 \mathrm{~mL}$ volume from the T. harzianum cultivation were taken every $24 \mathrm{~h}$ for determination of glucose and protein concentration. To prevent clogging of the sample port by $T$. harzianum, a $0.45 \mu \mathrm{m}$ filter-membrane (860.300.330, Trace analytics, Germany) surrounded the sample port. The glucose concentration was measured using a D-glucose assay kit (K-GLUC, Megazyme, USA) according to the manufacturer's instructions. The protein concentration was measured using a Bradford assay with bovine serum albumin as a reference. The protein composition was analyzed by Bolt ${ }^{\mathrm{TM}} 10 \%$ bis-Tris plus SDS-PAGE (NW00100BOX, Thermo Fisher Scientific, the Netherlands).

\section{Enzymatic activity assay}

\section{Aliquots of lipid accumulated S. occidentalis cells}

For activity assays of the TMEs lipid accumulated $S$. occidentalis, cells were grown according to Lamers et al. (2016). The cells were harvested and separated from the supernatant by centrifuging for $5 \mathrm{~min}$ at $3894 \times g$ at $20^{\circ} \mathrm{C}$. The $S$. occidentalis cells were washed with demi water to remove media components and centrifuged for $5 \mathrm{~min}$ at $3894 \times g$ at $20{ }^{\circ} \mathrm{C}$. The $S$. occidentalis pellet was resuspended in demi water until a concentration of $30 \%(\mathrm{v} / \mathrm{v})$. 
Aliquots of $3 \mathrm{~mL}$ of $30 \%(\mathrm{v} / \mathrm{v})$ S. occidentalis cells containing microbial oil were stored at $-20{ }^{\circ} \mathrm{C}$ for further use.

\section{S. occidentalis pretreatment}

A pretreatment step was introduced to weaken the cell wall. Different chemical and physical pretreatment techniques were performed as listed in Table 2. A volume of $3 \mathrm{~mL}$ of $30 \%(\mathrm{v} / \mathrm{v})$ S. occidentalis cells containing microbial oil were mixed with $10 \mathrm{~mL}$ of the different chemicals. Each mixture was incubated for $24 \mathrm{~h}$ at room temperature in a rotary wheel at $20 \mathrm{rpm}$ with a radius of $15 \mathrm{~cm}$. The microwave method of pretreatment was adapted from Jin et al. (2012) and performed with $10 \mathrm{~mL}$ of demi water, incubated for $10 \mathrm{~min}$ at $700 \mathrm{~W}$. The autoclave pretreatment was an incubation at $121{ }^{\circ} \mathrm{C}$ for $20 \mathrm{~min}$. After each pretreatment step the sample was centrifuged for $5 \mathrm{~min}, 1202 \times g$ at room temperature. The supernatant was discarded and the pellet was washed with $5 \mathrm{~mL}$ of demi water followed by $5 \mathrm{~mL}$ of citrate-phosphate buffer (40\% of $0.1 \mathrm{M}$ citric acid and $60 \%$ of $0.2 \mathrm{M} \mathrm{Na}_{2} \mathrm{PO}_{4}$ to reach a $\mathrm{pH}$ of 5.8). The mixture was centrifuged again for $5 \mathrm{~min}$ at $1202 \times g$ at room temperature. The supernatant was discarded and the remaining pellet $(\sim 1 \mathrm{~mL})$ was diluted with demi water to obtain $30 \%(\mathrm{v} / \mathrm{v})$ pretreated $S$. occidentalis cells containing microbial oil. Aliquots of 300 $\mu \mathrm{L}$ of pretreated $S$. occidentalis cells containing microbial

\begin{tabular}{|c|c|c|}
\hline $\begin{array}{l}\text { Sample } \\
\text { number }\end{array}$ & Method/added chemical & Effect \\
\hline 1 & $1 \mathrm{M} \mathrm{NaCl}$ & Osmotic pressure \\
\hline 2 & $1 \mathrm{M} \mathrm{NaOH}$ & Strong base \\
\hline 3 & $1 \mathrm{M} \mathrm{NH}_{4} \mathrm{OH}$ & Weak base \\
\hline 4 & $1 \mathrm{M} \mathrm{HCl}$ & Strong acid \\
\hline 5 & $1 \mathrm{M} \mathrm{H}_{3} \mathrm{PO}_{4}$ & Weak acid \\
\hline 6 & $1 \mathrm{M} \mathrm{CH}_{3} \mathrm{COOH}$ & Weak acid \\
\hline 7 & Microwave (700 W/10 min) & Heat/radiation \\
\hline 8 & $1 \%(v / v)$ Triton X-100 & Detergent \\
\hline 9 & $1 \%(v / v)$ Tween-80 & Detergent \\
\hline 10 & $50 \mathrm{mM}$ DTT & Detergent \\
\hline 11 & Autoclaved $\left(121^{\circ} \mathrm{C} / 20 \mathrm{~min}\right)$ & Heat/pressure \\
\hline 12 & Demi water + demi water & Negative control \\
\hline 13 & Demi water + TMEs & Negative control \\
\hline 14 & $1 \mathrm{M} \mathrm{NaOH}+$ demi water & Negative control \\
\hline 15 & $1 \mathrm{M} \mathrm{HCl}+$ demi water & Negative control \\
\hline 16 & $\begin{array}{l}\text { Autoclaved }\left(121^{\circ} \mathrm{C} / 20 \mathrm{~min}\right)+\text { demi } \\
\text { water }\end{array}$ & Negative control \\
\hline
\end{tabular}

A volume of $3 \mathrm{~mL}$ of $30 \%(\mathrm{v} / \mathrm{v})$ fat Schwanniomyces occidentalis cells was submitted to $10 \mathrm{~mL}$ of a chemical listed below. For the microwave, autoclave sterilization, and negative control, $10 \mathrm{~mL}$ of demi water was used. Pretreatments were performed for $24 \mathrm{~h}$ unless stated otherwise oil were stored at $-20{ }^{\circ} \mathrm{C}$ until required. To further investigate successful pretreatments, a dilution series of $1 \mathrm{M}, 0.5 \mathrm{M}$, and $0.1 \mathrm{M}$ of $\mathrm{NaOH}$ was tested.

A $300 \mu \mathrm{L}$ aliquot of the pretreated S. occidentalis cells containing microbial oil were incubated with $50 \mu \mathrm{L}$ of citrate-phosphate buffer ( $40 \%$ of $0.1 \mathrm{M}$ citric acid and $60 \%$ of $0.2 \mathrm{M} \mathrm{Na}_{2} \mathrm{PO}_{4}$ to reach a $\mathrm{pH}$ of 5.8 ) and $900 \mu \mathrm{L}$ of TMEs to a final protein concentration of $187 \mathrm{mg} \mathrm{L}^{-1}$. This mixture was vortexed for $1 \mathrm{~min}$ and thereafter incubated at $1000 \mathrm{rpm}$ at $30^{\circ} \mathrm{C}$ in a thermomixer (Thermomixer Compact, Eppendorf, the Netherlands) for $4 \mathrm{~h}$ and $24 \mathrm{~h}$. The release of oil from $\mathrm{S}$. occidentalis was visualized by adding $15 \mu \mathrm{L}$ Nile red (7726.1, Carl Roth, Germany) solution ( $1 \mathrm{mg} \mathrm{mL}^{-1}$ Nile red dissolved in acetone) to $S$. occidentalis and vortexed for $1 \mathrm{~min}$. Finally, the mixture was centrifuged for $5 \mathrm{~min}$ at $2902 \times g$ at room temperature. Microbial oil released from the cell is then seen as a pink layer on top of the solution.

\section{TME activity screening}

TME activity parameters were screened using the following factors: temperature $\left(10,40\right.$, and $\left.70{ }^{\circ} \mathrm{C}\right), \mathrm{pH}(3.0,5.0$, and 7.0), and incubation time (1, 4, and $24 \mathrm{~h})$. The experiment was performed in duplicate resulting in 54 samples. For all samples, $3 \mathrm{~mL}$ of $30 \%(\mathrm{v} / \mathrm{v})$ fat $S$. occidentalis pretreated with $1 \mathrm{M}$ of $\mathrm{NaOH}$ was mixed in $3 \mathrm{~mL}$ buffer at different $\mathrm{pH}(3.0,5.0,7.0)$ and $9 \mathrm{~mL}$ of TMEs to a final protein concentration of $187 \mathrm{mg} \mathrm{L}^{-1}$ of TMEs. The buffers used were $0.1 \mathrm{M}$ glycine- $\mathrm{HCl}$ buffer for $\mathrm{pH}$ 3.0, $0.1 \mathrm{M}$ citrate buffer for $\mathrm{pH}$ 5.0, and $0.1 \mathrm{M}$ phosphate buffer for $\mathrm{pH}$ 7.0. To set the $\mathrm{pH}$ either $6 \mathrm{M} \mathrm{H}_{3} \mathrm{PO}_{4}$ or $6 \mathrm{M} \mathrm{NaOH}$ was used. The tubes were incubated vertically at $250 \mathrm{rpm}$ for $24 \mathrm{~h}$ (New Brunswick ${ }^{\mathrm{TM}}$ Innova ${ }^{\circledR}$ 40, Eppendorf, the Netherlands). After performing the TME activity assay, the remaining $S$. occidentalis pellet was isolated from the supernatant by centrifugation for $30 \mathrm{~min}$ at $3871 \times g$ at room temperature, and used for oil content analysis using gas chromatography. For the optimization experiments, 0.1 and $0.5 \mathrm{M} \mathrm{NaOH}$ as a pretreatment step were used and the experiments were performed as stated above. For the enzyme concentration experiments $1 \mathrm{M} \mathrm{NaOH}$ for $24 \mathrm{~h}$ was performed as a pretreatment step, and TME concentrations of $187,93.6,46.8,18.7$, and $9.36 \mathrm{mg} \mathrm{L}^{-1}$ were used for 4 and $24 \mathrm{~h}$ of incubation time. Enzyme concentrations were determined via Bradford assay.

\section{Total lipid analysis of fatty acids by gas chromatography}

The remaining oil content in the $S$. occidentalis pellet was measured using gas chromatography by first freezedrying the cells and methylation of the samples thereafter. As a positive control, a volume of $1 \mathrm{~mL} 20 \%$ boron trifluoride-methanol was added to $30 \mathrm{mg}$ of freezedried $30 \%(\mathrm{v} / \mathrm{v})$ fat S. occidentalis cells. A calibration 
curve was made using pentadecanoic acid (76560-5ML, Sigma Aldrich, the Netherlands). A $100 \mu \mathrm{L}$ solution of $10 \mathrm{mg} \mathrm{g}^{-1}$ heptadecanoic acid (H3500-25G, Sigma Aldrich, the Netherlands) in heptane was added as an internal standard to each sample. A volume of $900 \mu \mathrm{L}$ heptane was added before the mixture was incubated overnight in a heating block at $70{ }^{\circ} \mathrm{C}$. Thereafter, the samples were cooled to room temperature, $5 \mathrm{~mL}$ of demi water was added and centrifuged at $1000 \times g$ for $10 \mathrm{~min}$ at room temperature. The heptane layer was transferred to a fresh vial to which $2 \mathrm{~mL}$ of demi water was added, and centrifuged again at $1000 \times g$ for $10 \mathrm{~min}$ at room temperature. A volume of $200 \mu \mathrm{L}$ of supernatant was added to a gas chromatography (GC) vial. The resulting fatty acid methyl esters (FAMEs) were analyzed by GC in combination with a flame ionization detector. The FAME analysis was performed with a GC-2030 (Shimadzu), which was equipped with a Stabilwax (Restek) column of $30 \mathrm{~m} \times 320 \mu \mathrm{m} \times 0.25 \mu \mathrm{m}$. The flow of the carrier gas (hydrogen) was set to $2 \mathrm{~mL} \mathrm{~min}^{-1}$ and the injection of 1 $\mu \mathrm{L}$ sample was carried out in split mode (ratio 1:10) at $230{ }^{\circ} \mathrm{C}$. The oven was set to $65^{\circ} \mathrm{C}$ for $30 \mathrm{~s}$, then temperature was increased to $220^{\circ} \mathrm{C}$ at a rate of $30^{\circ} \mathrm{C} \mathrm{min}^{-1}$ (held for $60 \mathrm{~s}$ ) and subsequently increased further to $240^{\circ} \mathrm{C}$ at a rate of $10{ }^{\circ} \mathrm{C} \mathrm{min}{ }^{-1}$ (held for $80 \mathrm{~s}$ ). The temperature of the detector was set to $240{ }^{\circ} \mathrm{C}$.

\section{LC-MS/MS analysis}

\section{Sample preparation}

LC-MS/MS analysis was performed for identification of the proteins produced by $T$. harzianum. The proteins were separated by SDS-PAGE and 6 protein bands were excised from the gel for LC-MS/MS analysis. Subsequently, the proteins were reduced by incubating the gel pieces in $10 \mathrm{mM}$ dithiothreitol (DTT) in $25 \mathrm{mM}$ ammonium bicarbonate at $55{ }^{\circ} \mathrm{C}$ for $45 \mathrm{~min}$. Then, the proteins were alkylated by incubating the gel pieces in $55 \mathrm{mM}$ iodoacetamide in $25 \mathrm{mM}$ ammonium bicarbonate at room temperature in the dark for $45 \mathrm{~min}$. Finally, the gel pieces were washed with $25 \mathrm{mM}$ ammonium bicarbonate, destained twice with $10 \%(\mathrm{v} / \mathrm{v})$ acetic acid in 50\% (v/v) ethanol at $37^{\circ} \mathrm{C}$ for $30 \mathrm{~min}$, and dried in a Savant SpeedVac SPD121P (Thermo Fisher Scientific, the Netherlands) for $10 \mathrm{~min}$.

\section{Enzymatic digestion}

The gel pieces with the reduced and alkylated proteins were incubated with $0.1 \mathrm{~g} \mathrm{~L}^{-1}$ trypsin in $50 \mathrm{mM}$ ammonium bicarbonate at $37^{\circ} \mathrm{C}$ for $24 \mathrm{~h}$. After digestion, the peptides were extracted two times by incubating the gel with $60 \%(\mathrm{v} / \mathrm{v})$ acetonitrile containing $0.1 \%(\mathrm{v} / \mathrm{v})$ formic acid at $300 \mathrm{rpm}$ and $37^{\circ} \mathrm{C}$ for $1 \mathrm{~h}$. The extracts were combined and stored at $-20^{\circ} \mathrm{C}$ until analysis.

\section{Analysis}

The peptides in the protein hydrolysates were separated using a Dionex Ultimate 3000 LC system (Thermo Fisher Scientific, the Netherlands) equipped with a Zorbax XDB C18 column $(4.6 \times 50 \mathrm{~mm}, 1.6 \mu \mathrm{m}$ particle size; Agilent Technologies, USA). The hydrolysates $(10 \mu \mathrm{L})$ were injected onto the column thermoregulated at $30{ }^{\circ} \mathrm{C}$. For the separation of the peptides, the following elution profile was used: $0-0.5 \mathrm{~min}$ isocratic on $10 \% \mathrm{~B} ; 0.5-10 \mathrm{~min}$ linear gradient from 10 to $90 \% \mathrm{~B} ; 10-14 \mathrm{~min}$ isocratic on $90 \%$ B; $14-17$ min linear gradient from 90 to $10 \%$ B and 17-20 min isocratic on $10 \% \mathrm{~B}$. Eluent A was milliQ water containing $0.1 \%(\mathrm{v} / \mathrm{v})$ formic acid and eluent $\mathrm{B}$ was $100 \% \mathrm{MeOH}$ containing $0.1 \%(\mathrm{v} / \mathrm{v})$ formic acid. The flow rate was $0.3 \mathrm{~mL} \mathrm{~min}{ }^{-1}$. MS data of the hydrolysates were acquired with an online amaZon SL ion-trap MS using HyStar software v3.2 (Bruker Daltonik GmBH, Germany). MS and MS/MS analysis were performed with enhanced resolution as scan mode and ESI in positive mode.

\section{Protein identification}

Raw MS data were processed with Compass Data Analysis v4.2 (Bruker Daltonik GmBH, Germany) and proteins were identified using BioTools v3.2 (Bruker Daltonik $\mathrm{GmBH}$, Germany) with the Mascot search engine. Peptide sequence matching was first performed against the NCBIprot database without specified taxonomy to check for contamination (e.g. proteins from S. occidentalis) and false positives. Peptide sequence matching was then performed against the NCBIprot database with other fungi as taxonomy. Carbamidomethylation of cysteine was set as global modification and missed cleavages by trypsin were excluded. Mass error tolerances for annotation were set to $0.15 \mathrm{Da}$ and 0.5 Da for MS and MS/ MS, respectively. Peptides were identified when $p<0.05$. The presence of identified proteins was classified as significant with low reliability for proteins originating from $T$. harzianum with $\leq$ two identified peptides. To analyse the predicted proteins, BLAST and DeepLoc algorithms were used (Altschul et al. 1990; Almagro Armenteros et al. 2017).

\section{Results}

\section{Bioreactor cultivation}

A cultivation procedure using bioreactors was performed to produce tailor-made enzymes (TMEs) by T. harzianum fed with wet biomass of non-fat S. occidentalis grown on YPD. Every $24 \mathrm{~h}$ samples were taken and analyzed for glucose and protein content (Fig. 2). After $19 \mathrm{~h}$ the batch phase of T. harzianum was completed, since no glucose was present anymore, and the addition of $S$. occidentalis was started by pumping 


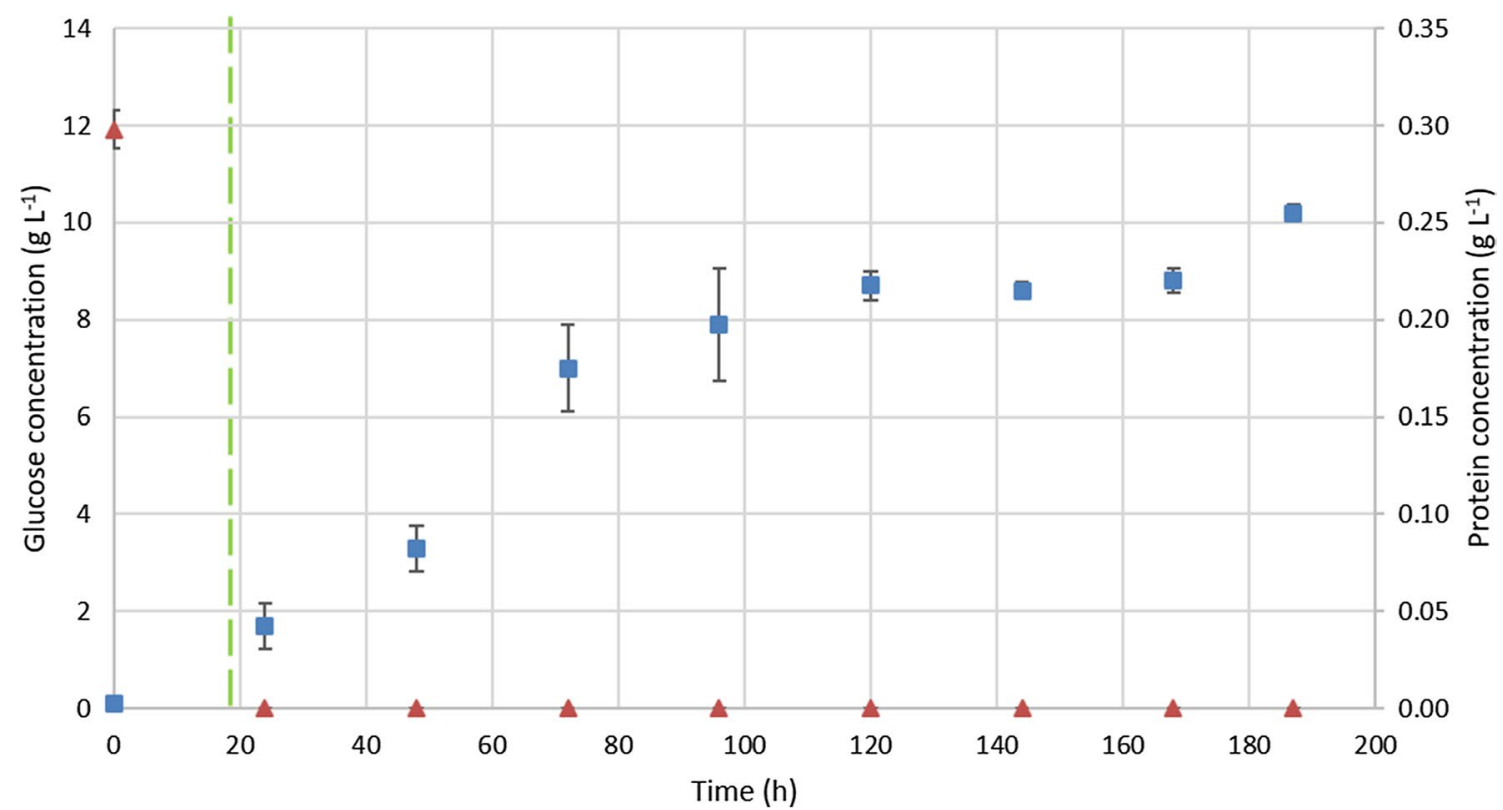

Fig. 2 Glucose and protein content analysis of the bioreactor cultivation. Glucose (orange traingle) and protein (blue sqaure) concentration over time during the Trichoderma harzianum cultivation. After $19 \mathrm{~h}$ the fed-batch phase was initiated using Schwanniomyces occidentalis as feed (green dashed line). The glucose concentration remained at $0 \mathrm{~g} \mathrm{~L}^{-1}$ from this time on, while the protein content increased towards $0.26 \mathrm{~g} \mathrm{~L}^{-1}$. After $187 \mathrm{~h}$ the cultivation was stopped and the supernatant containing the tailor-made enzymes (TMEs) was harvested

it as a feed into the bioreactor until the cultivation was stopped after $187 \mathrm{~h}$. The glucose concentration remained at $0 \mathrm{~g} \mathrm{~L}^{-1}$ throughout the entire feeding phase with $S$. occidentalis. However, the protein concentration increased during this phase to $0.26 \mathrm{~g} \mathrm{~L}^{-1}$ at the moment of harvesting the supernatant. The resulting broth was stored at $-20{ }^{\circ} \mathrm{C}$ until further enzymatic analysis.

\section{Enzymatic activity assay}

After preparation of the TMEs and the lipid accumulated $S$. occidentalis cells, we investigated which pretreatment was most suitable for further experiments. As shown with the Nile red staining, $1 \mathrm{M} \mathrm{NaOH}$ was the most promising pretreatment as lipids were released and visible in the upper layer after centrifugation (Fig. 3). One other chemical $(1 \mathrm{M} \mathrm{HCl})$ and the autoclavation procedure also reacted positively. However, it was decided to continue with $\mathrm{NaOH}$, since this pretreatment released

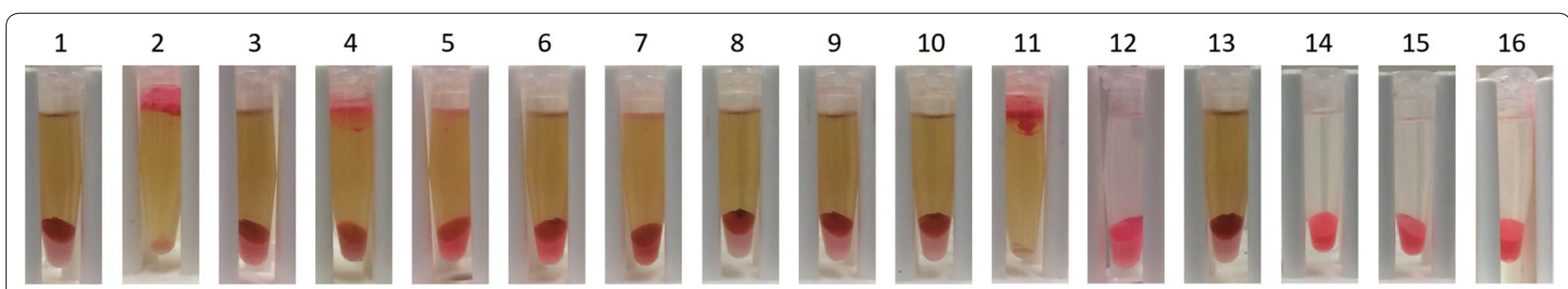

Fig. 3 Pretreatment screening analysis. The pretreatment screening analysis exposed the Schwanniomyces occidentalis fat cells to chemicals, microwave or autoclaving pretreatment for $24 \mathrm{~h}$ prior to addition of the tailor-made enzymes (TMEs). The release of oil was visualized after $24 \mathrm{~h}$ of TME incubation time by the addition of Nile red. Sample (1) $1 \mathrm{M} \mathrm{NaCl}$, (2) $1 \mathrm{M} \mathrm{NaOH}$, (3) $1 \mathrm{M} \mathrm{NH}_{4} \mathrm{OH}$, (4) $1 \mathrm{M} \mathrm{HCl}$, (5) $1 \mathrm{M} \mathrm{H}_{3} \mathrm{PO}_{4}$, (6) $1 \mathrm{M} \mathrm{CH}_{3} \mathrm{COOH}_{\text {, (7) }}$ microwave procedure (700 W, $10 \mathrm{~min}),(8) 1 \%(\mathrm{v} / \mathrm{v})$ Triton X-100, (9) 1\% (v/v) Tween-80, (10) $\left.50 \mathrm{mM} \mathrm{DTT,} \mathrm{(11)} \mathrm{autoclave} \mathrm{procedure} \mathrm{(121}{ }^{\circ} \mathrm{C} / 20 \mathrm{~min}\right)$, (12) control sample with demi water as a pretreatment step and demi water as a lysis procedure, (13) control sample with demi water as a pretreatment step and lytic enzymes as a lysis procedure, (14) control sample with $1 \mathrm{M} \mathrm{NaOH}$ as pretreatment step and demi water as a lysis procedure, (15) control sample with $\mathrm{HCl}$ as a pretreatment step and demi water as a lysis procedure, (16) control sample by autoclave procedure $\left(121^{\circ} \mathrm{C} / 20 \mathrm{~min}\right)$ and demi water as a lysis procedure 
more oil from the cells compared to pretreatment with $\mathrm{HCl}$ (Fig. 3) and is energetically more favorable compared to autoclavation. Next, a concentration series of $1,0.5$, and $0.1 \mathrm{M}$ of $\mathrm{NaOH}$ was tested and incubated for $24 \mathrm{~h}$ (Fig. 4). Following the incubation, the TMEs were added for $4 \mathrm{~h}$ or $24 \mathrm{~h}$. These results showed that the best pretreatments to yield oil were either $1 \mathrm{M}$ of $\mathrm{NaOH}$ with a $4 \mathrm{~h}$ TME incubation time, or $0.5 \mathrm{M} \mathrm{NaOH}$ using $24 \mathrm{~h}$ of incubation time with TMEs. It was chosen to continue with the $1 \mathrm{M} \mathrm{NaOH}$ pretreatment step because the TME incubation time step is less time consuming. A dilution series of TME concentration showed that the TMEs were active against $S$. occidentalis at a concentration of $93.6 \mathrm{mg} \mathrm{L}^{-1}$ at $4 \mathrm{~h}$ incubation time, or at a concentration of $18.7 \mathrm{mg} \mathrm{L}^{-1}$ at $24 \mathrm{~h}$ incubation time (Fig. 5). However, the best results, where there is complete disruption and no oil remains in the pellet, were obtained using a TME concentration of $187 \mathrm{mg} \mathrm{L}^{-1}$ and $4 \mathrm{~h}$ incubation time, or $46.8 \mathrm{mg} \mathrm{L}^{-1}$ and $24 \mathrm{~h}$ incubation time.

\section{Oil content analysis}

The TME activity was tested by measuring the oil content in the cell pellets using gas chromatography (Table 3).

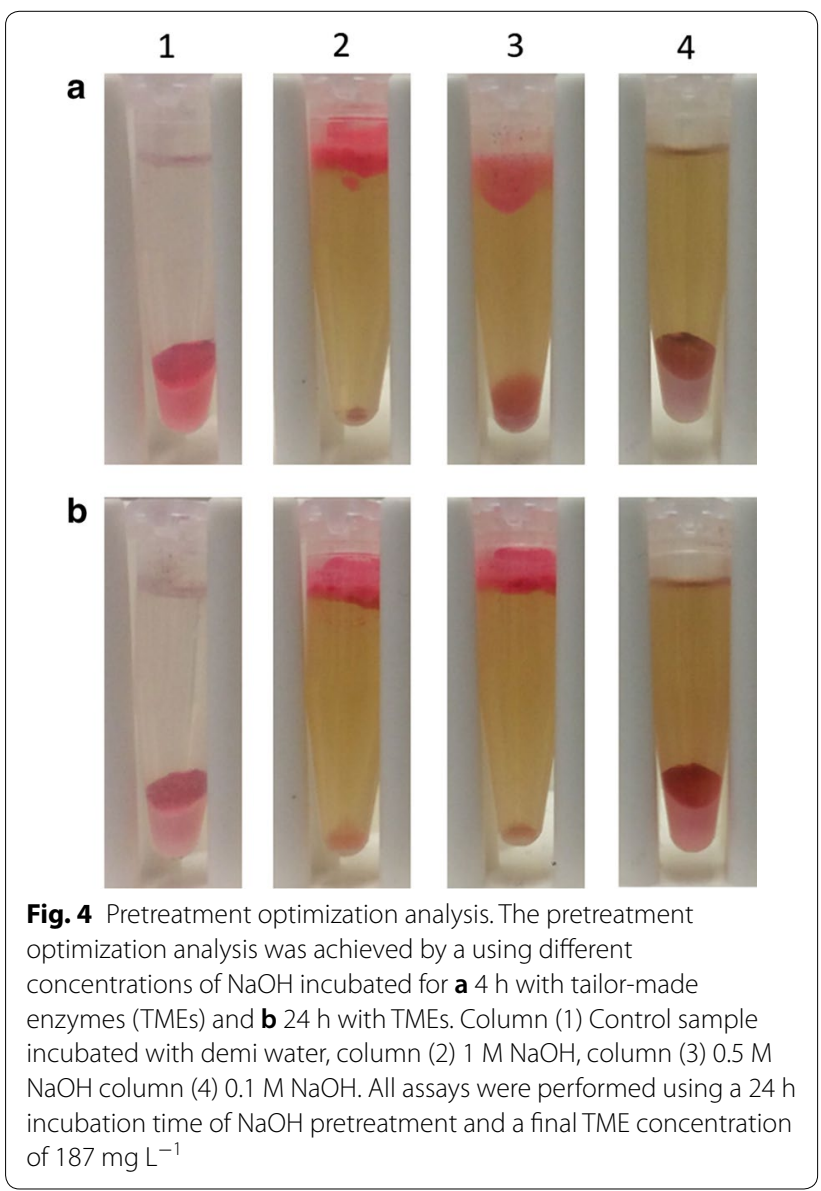

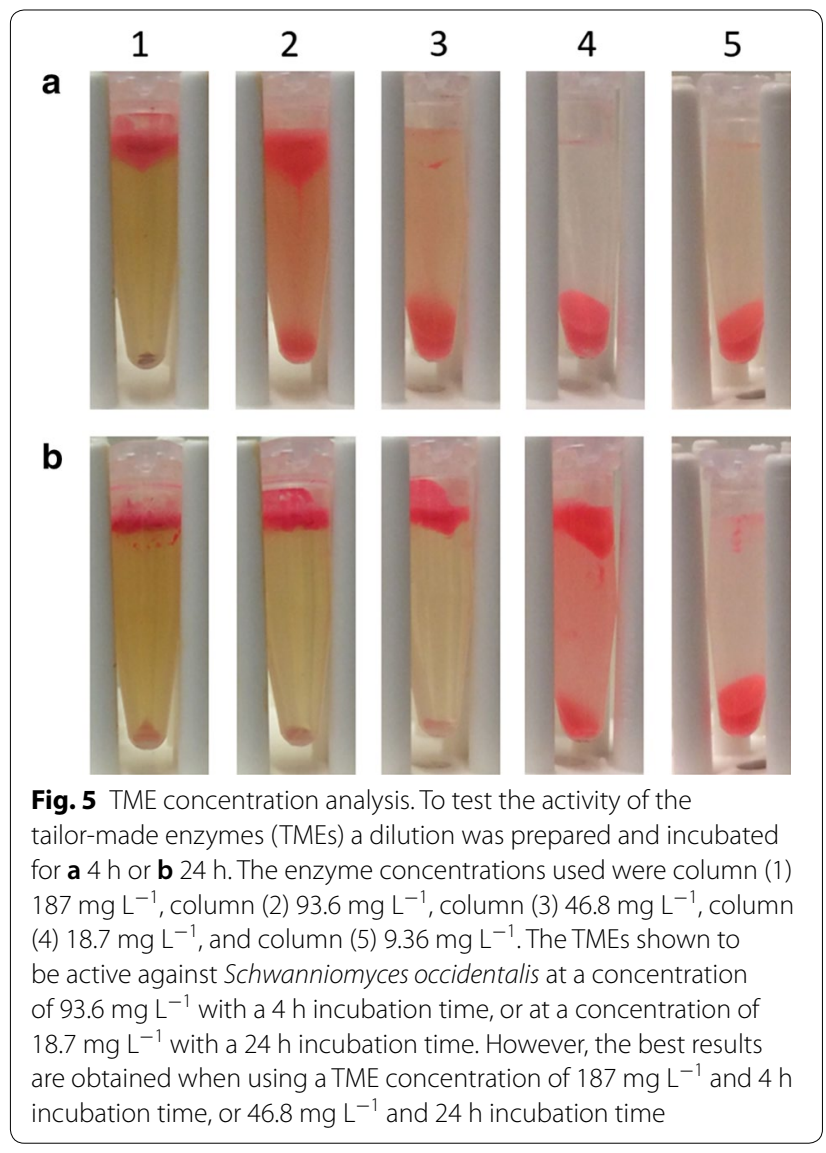

Unfortunately, released oil on top of the samples could not be measured with reproducible values, since the top layer was fragile and hard to sample in a consistent manner (data not shown). The sample that released the most oil was obtained using the TMEs at pH 5 at $40{ }^{\circ} \mathrm{C}$ for $4 \mathrm{~h}$ of incubation time. These conditions released all the oil from the cells $(0.00 \pm 0.00 \mathrm{mg}$ remaining in the pellet). Similarly, using the same conditions but an incubation time of $24 \mathrm{~h}$ also released the majority of the oil $(0.04 \pm 0.05 \mathrm{mg})$. Positive results were also obtained for pretreatment conditions of $\mathrm{pH} 3$ at $40{ }^{\circ} \mathrm{C}$ for $24 \mathrm{~h}$ $(0.90 \pm 0.07 \mathrm{mg})$, and at $\mathrm{pH} 5$ at $10{ }^{\circ} \mathrm{C}$ and $70{ }^{\circ} \mathrm{C}$ for $24 \mathrm{~h}$ $(1.07 \pm 0.27 \mathrm{mg}$ and $0.40 \pm 0.18 \mathrm{mg}$, respectively). Based on these results, incubating $S$. occidentalis with TMEs at $\mathrm{pH} 5$ at $40{ }^{\circ} \mathrm{C}$ for $4 \mathrm{~h}$ is considered the best option due to the mild acidic environment and relatively low temperature and incubation time.

\section{LC-MS/MS analysis}

LC-MS/MS analysis was performed to identify the six main proteins produced by T. harzianum (Fig. 6). Two proteins were identified with high reliability; GenBank PKK54770.1 (band 2) and GenBank PKK55157.1 (band 4 and 5), have an amidase- and a sarcosine oxidase-domain, 
Table 3 Total oil content remaining in $30 \%(v / v)$ fat Schwanniomyces occidentalis pellet after using tailor-made enzymes in a variety of conditions in temperature, $\mathrm{pH}$, and time

\begin{tabular}{|c|c|c|c|c|}
\hline Sample & $\mathrm{pH}$ & $\begin{array}{l}\text { Temperature } \\
\left({ }^{\circ} \mathrm{C}\right)\end{array}$ & Time (h) & $\begin{array}{l}\text { Average oil } \\
\text { content in pellet } \\
(\mathrm{mg})\end{array}$ \\
\hline 1 & 3.0 & 10 & 1 & $67.59 \pm 4.02$ \\
\hline 2 & 3.0 & 10 & 4 & $67.44 \pm 2.11$ \\
\hline 3 & 3.0 & 10 & 24 & $19.69 \pm 3.26$ \\
\hline 4 & 3.0 & 40 & 1 & $64.61 \pm 2.33$ \\
\hline 5 & 3.0 & 40 & 4 & $65.82 \pm 1.66$ \\
\hline 6 & 3.0 & 40 & 24 & $0.90 \pm 0.07$ \\
\hline 7 & 3.0 & 70 & 1 & $58.22 \pm 2.46$ \\
\hline 8 & 3.0 & 70 & 4 & $62.12 \pm 1.97$ \\
\hline 9 & 3.0 & 70 & 24 & $63.27 \pm 0.46$ \\
\hline 10 & 5.0 & 10 & 1 & $69.58 \pm 0.67$ \\
\hline 11 & 5.0 & 10 & 4 & $71.50 \pm 0.42$ \\
\hline 12 & 5.0 & 10 & 24 & $1.07 \pm 0.27$ \\
\hline 13 & 5.0 & 40 & 1 & $55.02 \pm 2.04$ \\
\hline 14 & 5.0 & 40 & 4 & $0.00 \pm 0.00$ \\
\hline 15 & 5.0 & 40 & 24 & $0.04 \pm 0.05$ \\
\hline 16 & 5.0 & 70 & 1 & $58.82 \pm 1.13$ \\
\hline 17 & 5.0 & 70 & 4 & $56.89 \pm 0.52$ \\
\hline 18 & 5.0 & 70 & 24 & $0.40 \pm 0.18$ \\
\hline 19 & 7.0 & 10 & 1 & $67.05 \pm 1.70$ \\
\hline 20 & 7.0 & 10 & 4 & $66.17 \pm 2.34$ \\
\hline 21 & 7.0 & 10 & 24 & $70.48 \pm 2.81$ \\
\hline 22 & 7.0 & 40 & 1 & $66.57 \pm 2.32$ \\
\hline 23 & 7.0 & 40 & 4 & $70.64 \pm 3.00$ \\
\hline 24 & 7.0 & 40 & 24 & $66.49 \pm 2.50$ \\
\hline 25 & 7.0 & 70 & 1 & $68.59 \pm 3.47$ \\
\hline 26 & 7.0 & 70 & 4 & $74.30 \pm 3.77$ \\
\hline 27 & 7.0 & 70 & 24 & $67.90 \pm 0.79$ \\
\hline \multicolumn{5}{|c|}{ Controls — demi water, no enzymes } \\
\hline 28 & 3.0 & 70 & 24 & $74.91 \pm 0.15$ \\
\hline 29 & 5.0 & 70 & 24 & $75.07 \pm 0.24$ \\
\hline 30 & 7.0 & 70 & 24 & $61.24 \pm 0.05$ \\
\hline
\end{tabular}

The oil content is an average of three technical measurement of a biological duplicate experiment, hence an average of six measurements

respectively (Table 4). Three other proteins were identified with low reliability (i.e. based on only one peptide hit). These proteins have a serine protease domain (GenBank PKK45954.1; band 1 and 4), a glycoside hydrolase/

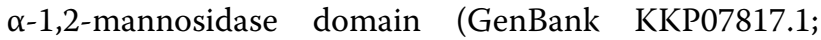
band 3) and a $\beta$-1,6-glucanase domain (GenBank ACM42428.1; band 5). All proteins were predicted to be extracellular, with the exception of PKK55157.1, which was predicted to be in the peroxisome. The protein with the lowest molecular weight $( \pm 32 \mathrm{kDa})$ did not result in a significant hit and remains unidentified.

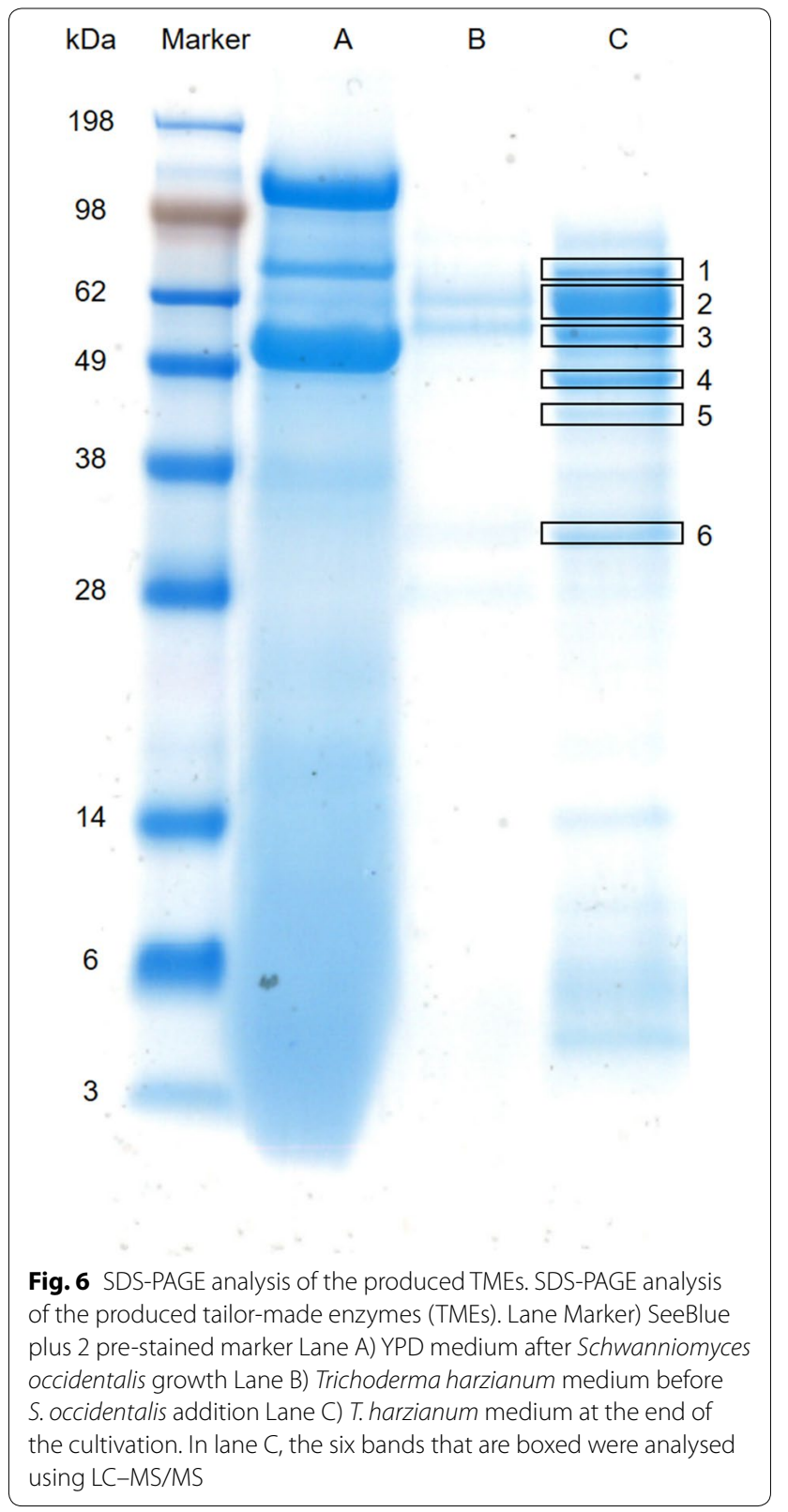

\section{Discussion}

The activity of the TMEs show $S$. occidentalis cells can be successfully disrupted and oil can be released (Figs. 4 and 5). The resulting TMEs are a mixture of proteins including proteases, sarcosine oxidases, amidases, mannosidases, and glucanases. It was possible to show that all proteins originate from $T$. harzianum, indicating the absence of contamination from other organisms and degraded proteins from S. occidentalis (Fig. 6 and Table 4). Except for $\beta$-1,6-glucanase (GenBank ACM42428.1), all identified proteins were predicted based on the sequence data of T. harzianum and have been confirmed in this 


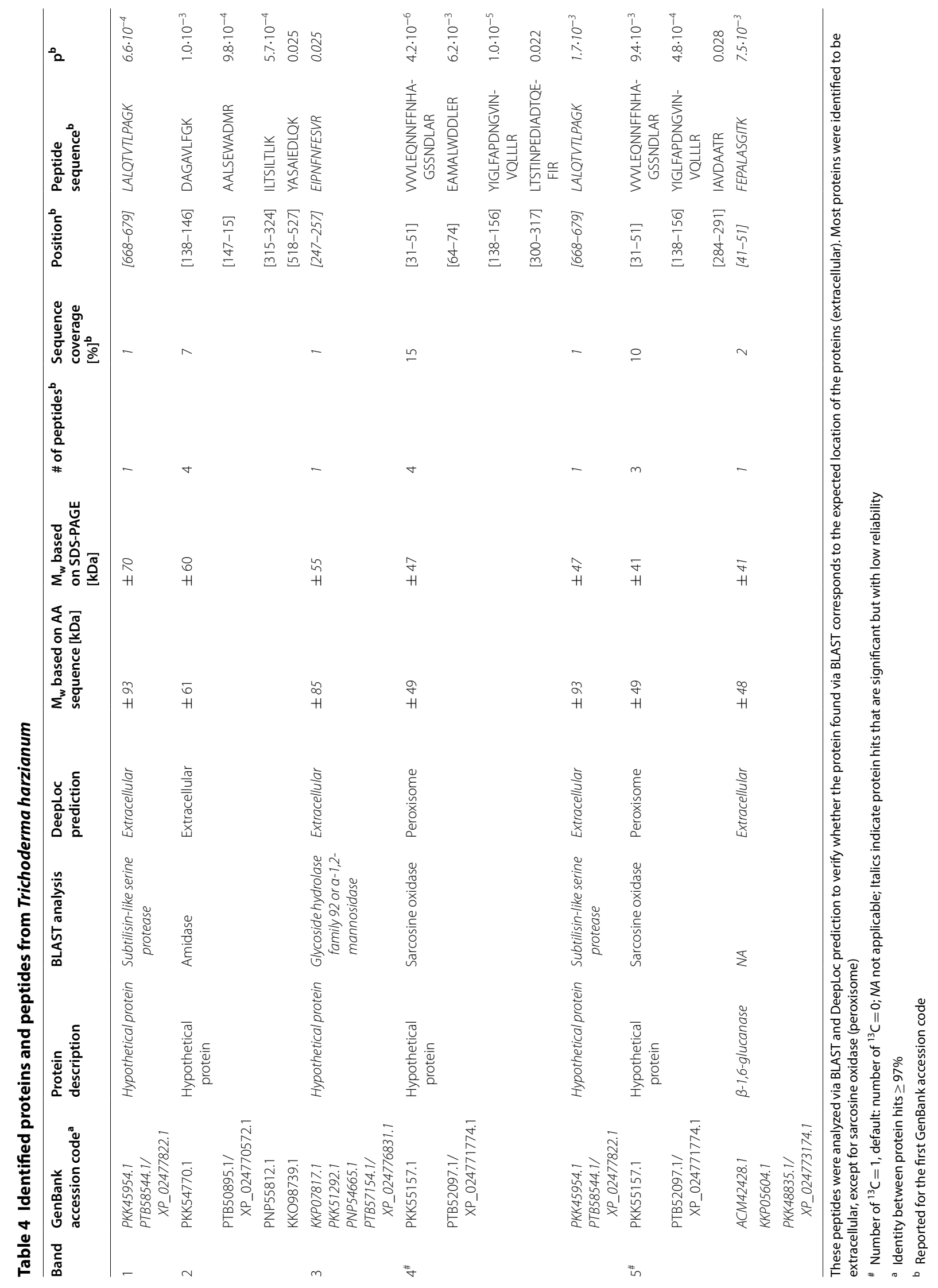


study (Table 4). The hypothetical protein sarcosine oxidase (GenBank PKK55157.1, $\pm 49 \mathrm{kDa}$ ) was identified in band $4( \pm 47 \mathrm{kDa})$ as well as in band $5( \pm 41 \mathrm{kDa})$. Possible reasons may be degradation of the protein due to its extracellular presence instead of the predicted peroxisome, co-diffusion through the gel, or splicing in the corresponding gene (Xie et al. 2015). Chitinase was not detected in the TME mixture. This suggests that either the cell wall of $S$. occidentalis does not contain chitin, or that chitinase is not produced by T. harzianum in sufficient quantity to be detected by LC-MS/MS. The latter is more likely as chitin is expected to be present in the cell wall of $S$. occidentalis, based on the robustness of $S$. occidentalis cell wall and the fact that chitin is known to contribute to the strength of cell walls (Arroyo et al. 2016; Lamers et al. 2016). Moreover, chitin is found in many fungal cell walls such as Candida sp., and as Schwanniomyces sp. are closely related to Candida sp. this supports the hypothesis that $S$. occidentalis will have a cell wall comprising chitin (Erwig and Gow 2016; Breuer and Harms 2006). Furthermore, chitinase activity and presence has been identified by previous nLC-MS/ MS experiments when grown on chitin-rich medium (Urbina-Salazar et al. 2018). Three different chitinases were identified with a molecular weight of 31,50 , and $82 \mathrm{kDa}$. It could be that band 6 in Fig. 6 represents a chitinase, since it is within the range of $31 \mathrm{kDa}$. Unfortunately, the identity of this protein could not be confirmed in this study.

The TME concentration analysis shows the enzyme concentration needed for disruption of $S$. occidentalis cells is dependent upon the duration of TME incubation time; a higher enzyme concentration requires a shorter incubation time (Fig. 5). We expect the enzymes used in this process are the cost-limiting factor and minimizing enzyme concentration will be both economically and practically beneficial for the overall process. Despite these settings, pretreatment with $1 \mathrm{M} \mathrm{NaOH}$ is still necessary to disrupt the yeast cells, and is often applied in combination with heat (Safi et al. 2014; Fontaine et al. 2000). It can be concluded that the use of $1 \mathrm{M} \mathrm{NaOH}$ as pretreatment in combination with the TMEs makes the heating step redundant (Fig. 4 and Table 3). However, $S$. occidentalis is degraded when used as feed for T. harzianum without the use of a $\mathrm{NaOH}$ pretreatment (Fig. 6). Consequently, we hypothesize that $T$. harzianum proteins expressed in the cell wall mimic the pretreatment step that is necessary for the extracellular enzymes to function. These proteins could be located in the Papillalike structures of $T$. harzianum, since many genes coding for both intracellular as well as extracellular proteins are upregulated during mycoparasitism (Atanasova et al. 2013; Druzhinina et al. 2011). It is of interest to identify these proteins and to add them to the TMEs to generate a one-step microbial oil extraction method.

In conclusion, this study demonstrates that microbial oil can be released from S. occidentalis using a pretreatment of $1 \mathrm{M}$ of $\mathrm{NaOH}$ followed by TME incubation for $4 \mathrm{~h}$ at a concentration of $187 \mathrm{mg} \mathrm{L}^{-1}$, or using an incubation time of $24 \mathrm{~h}$ using $46.8 \mathrm{mg} \mathrm{L}^{-1} \mathrm{TME}$ concentration. No further treatment needs to be performed with the TMEs themselves and they can be used directly from the cultivation broth. Furthermore, this procedure discards the highly energetically unfavorable pretreatment heating step currently used. These improvements bring microbial oil extraction one step closer towards an economically feasible process contributing to the biobased economy.

\section{Abbreviations}

GC: Gas chromatography; DTT: Dithiothreitol; FAME: Fatty acid methyl ester; LC-MS/MS: Liquid chromatography mass spectrometry/mass spectrometry; MS: Mass spectrometry; PDB: Potato dextrose broth; TME: Tailor-made enzyme; YPD: Yeast-extract peptone dextrose.

\section{Acknowledgements \\ Not applicable.}

\section{Authors' contributions}

$\mathrm{RH}$ designed and analysed the experiments, and wrote the manuscript. BV performed and analysed the experiments related to the cultivation, GC, and all enzyme activity experiments. EvdZ performed cultivation experiments. RvdV designed and performed the GC experiments. FK performed the LC-MS/ MS experiments. RD designed and analysed the LC-MS/MS experiments, and wrote the manuscript. RW analysed the data and wrote the manuscript. All authors read and approved the final manuscript.

\section{Funding}

This work was financially supported by the HAN University of Applied Sciences and Regieorgaan SIA (2014-1-06PRO).

\section{Availability of data and materials}

All data is digitally and privately stored via eLABJournal (subscription needed). Enzyme samples for research purposes can be obtained via a material transfer agreement. The strains used in this study are stored at the Westerdijk Fungal Biodiversity Institute (CBS-KNAW).

\section{Ethics approval and consent to participate} Not applicable.

\section{Consent for publication}

Not applicable.

\section{Competing interests}

The authors declare that they have no competing interests.

Received: 29 October 2019 Accepted: 19 February 2020

Published online: 28 February 2020

\footnotetext{
References

Ageitos JM, Vallejo JA, Veiga-Crespo P, Villa TG (2011) Oily yeasts as oleaginous cell factories. Appl Microbiol Biotechnol 90(4):1219-1227. https://doi. org/10.1007/s00253-011-3200-z

Almagro Armenteros JJ, Sønderby CK, Sønderby SK, Nielsen H, Winther O (2017) DeepLoc: prediction of protein subcellular localization using deep learning. Bioinformatics 33(21):3387-3395. https://doi.org/10.1093/bioin formatics/btx431
} 
Altschul SF, Gish W, Miller W, Myers EW, Lipman DJ (1990) Basic local alignment search tool. J Mol Biol 215(3):403-410. https://doi.org/10.1016/S0022 $-2836(05) 80360-2$

Arroyo J, Farkaš V, Sanz AB, Cabib E (2016) Strengthening the fungal cell wall through chitin-glucan cross-links: effects on morphogenesis and cell integrity. Cell Microbiol 18(9):1239-1250. https://doi.org/10.1111/ cmi.12615

Atanasova L, Le Crom S, Gruber S, Coulpier F, Seidl-Seiboth V, Kubicek CP, Druzhinina IS (2013) Comparative transcriptomics reveals different strategies of Trichoderma mycoparasitism. BMC Genomics 14:121. https://doi. org/10.1186/1471-2164-14-121

Athenaki M, Gardeli C, Diamantopoulou P, Tchakouteu SS, Sarris D, Philippoussis A, Papanikolaou S (2018) Lipids from yeasts and fungi: physiology, production and analytical considerations. J Appl Microbiol 124(2):336-367. https://doi.org/10.1111/jam.13633

Breuer H, Harms H (2006) Debaryomyces hansenii-an extremophilic yeast with biotechnological potential. Yeast 23(6):415-437. https://doi. org/10.1002/yea. 1374

de las Mercedes Dana M, Limón MC, Mejías R, Mach RL, Benítez T, Pintor-Toro JA, Kubicek CP (2001) Regulation of chitinase 33 (chit33) gene expression in Trichoderma harzianum. Curr Genet 38(6):335-342. https://doi. org/10.1007/s002940000169

Dong T, Knoshaug EP, Pienkos PT, Laurens LML (2016) Lipid recovery from wet oleaginous microbial biomass for biofuel production: a critical review. Appl Energy 177:879-895. https://doi.org/10.1016/j.apenergy.2016.06.002

Druzhinina IS, Seidl-Seiboth V, Herrera-Estrella A, Horwitz BA, Kenerley CM, Monte E, Hukherjee PK, Zeilinger S, Grigoriev IV, Kubicek CP (2011) Trichoderma: the genomics of opportunistic success. Nat Rev Microbiol 9(10):749-759. https://doi.org/10.1038/nrmicro2637

Elad Y, Chet I, Henis Y (1982) Degradation of plant pathogenic fungi by Trichoderma harzianum. Can J Microbiol 28(7):719-725. https://doi. org/10.1139/m82-110

Erwig LP, Gow NA (2016) Interactions of fungal pathogens with phagocytes. Nat Rev Microbiol 14(3):163-176. https://doi.org/10.1038/nrmic ro.2015.21

Fan H, Liu Z, Zhang R, Wang N, Dou K, Mijiti G, Diao G, Wang Z (2014) Functional analysis of a subtilisin-like serine protease gene from biocontrol fungus Trichoderma harzianum. J Microbiol 52(2):129-138. https://doi. org/10.1007/s12275-014-3308-9

Fontaine T, Simenel C, Dubreucq G, Adam O, Delepierre M, Lemoine J, Vorgias CE, Diaquin M, Latgé JP (2000) Molecular organization of the alkali-insoluble fraction of Aspergillus fumigatus cell wall. J Biol Chem 275(36):2759427607. https://doi.org/10.1074/jbc.M909975199

Ghasemi Naghdi F, González González LM, Chan W, Schenk PM (2016) Progress on lipid extraction from wet algal biomass for biodiesel production. Microb Biotechnol 9(6):718-726. https://doi. org/10.1111/1751-7915.12360

Gruber S, Seidl-Seiboth V (2012) Self versus non-self: fungal cell wall degradation in Trichoderma. Microbiology 158(Pt 1):26-34. https://doi. org/10.1099/mic.0.052613-0

Hao G, Chen H, Gu Z, Zhang H, Chen W, Chen YQ (2016) Metabolic engineering of Mortierella alpina for enhanced arachidonic acid production through the NADPH-supplying strategy. Appl Environ Microbiol 82(11):3280-3288. https://doi.org/10.1128/AEM.00572-16

Jin G, Yang F, Hu C, Shen H, Zhao ZK (2012) Enzyme-assisted extraction of lipids directly from the culture of oleaginous yeast Rhodosporidium turoloides. Bioresour Technol 111:378-382. https://doi.org/10.1016/j.biort ech.2012.01.152

Lamers D, van Biezen N, Martens D, Peters L, van de Zilver E, Jacobs-van Dreumel N, Wijffels RH, Lokman C (2016) Selection of oleaginous yeasts for fatty acid production. BMC Biotechnol 16(1):45. https://doi. org/10.1186/s12896-016-0276-7

Mukherjee M, Mukherjee PK, Horwitz BA, Zachow C, Berg G, Zeilinger S (2012) Trichoderma-plant-pathogen interactions: advances in genetics of biological control. Indian J Microbiol 52(4):522-529. https://doi.org/10.1007/ s12088-012-0308-5
Noronha EF, Ulhoa CJ (2000) Characterization of a 29-kDa beta-1,3-glucanase from Trichoderma harzianum. FEMS Microbiol Lett 183(1):119-123. https ://doi.org/10.1111/j.1574-6968.2000.tb08944.x

Papanikolaou S, Aggelis G (2011) Lipids of oleaginous yeasts. Part I: biochemistry of single cell oil production. Eur J Lipid Sci Technol 113:1031-1051. https://doi.org/10.1002/ejlt.201100014

Qualhato TF, Lopes FA, Steindorff AS, Brandão RS, Jesuino RS, Ulhoa CJ (2013) Mycoparasitism studies of Trichoderma species against three phytopathogenic fungi: evaluation of antagonism and hydrolytic enzyme production. Biotechnol Lett 35(9):1461-1468. https://doi.org/10.1007/ s10529-013-1225-3

Reithner B, Ibarra-Laclette E, Mach RL, Herrera-Estrella A (2011) Identification of mycoparasitism-related genes in Trichoderma atroviride. Appl Environ Microbiol 77(13):4361-4370. https://doi.org/10.1128/AEM.00129-11

Remmers IM, Hidalgo-Ulloa A, Brandt BP, Evers WAC, Wijffels RH, Lamers PP (2017) Continuous versus batch production of lipids in the microalgae Acutodesmus obliquus. Bioresour Technol 244(Pt 2):1384-1392. https://doi. org/10.1016/j.biortech.2017.04.093

Safi C, Ursu AV, Laroche C, Zebib B, Merah O, Pontalier PY, Vaca-Garcia C (2014) Aqueous extraction of proteins from microalgae: effect of different cell disruption methods. Algal Res 3:61-65. https://doi.org/10.1016/j.algal .2013 .12 .004

Seidl V, Song L, Lindquist E, Gruber S, Koptchinskyi A, Zeilinger S, Schmoll M, Martínez P, Sun J, Grigoriev I, Herrerra-Estralla A, Baker SE, Kubicek CP (2009) Transcriptomic response of the mycoparasitic fungus Trichoderma atroviride to the presence of a fungal prey. BMC Genomics 10:567. https:// doi.org/10.1186/1471-2164-10-567

Silva RN, da Silva SP, Brandão RL, Ulhoa CJ (2004) Regulation of N-acetyl-betaD-glucosaminidase produced by Trichoderma harzianum: evidence that cAMP controls its expression. Res Microbiol 155(8):667-671. https://doi. org/10.1016/j.resmic.2004.05.012

Sitepu I, Selby T, Lin T, Zhu S, Boundy-Mills K (2014a) Carbon source utilization and inhibitor tolerance of 45 oleaginous yeast species. J Ind Microb Biotechnol 41(7):1061-1070. https://doi.org/10.1007/s10295-014-1447-y

Sitepu IR, Garay LA, Sestric R, Levin D, Block DE, German JB, Boundry-Mills KL (2014b) Oleaginous yeasts for biodiesel: current and future trends in biology and production. Biotechnol Adv 32(7):1336-1360. https://doi. org/10.1016/j.biotechadv.2014.08.003

Steindorff AS, Ramada MH, Coelho AS, Miller RN, Pappas GJ Jr, Ulhoa CJ, Noronha EF (2014) Identification of mycoparasitism-related genes against the phytopathogen Sclerotinia sclerotiorum through transcriptome and expression profile analysis in Trichoderma harzianum. BMC Genomics 15:204. https://doi.org/10.1186/1471-2164-15-204

Urbina-Salazar A, Inca-Torres AR, Falcón-García G, Carbonero-Aguilar P, Rodríguez-Morgado B, del Campo JA, Parrado J, Bautista J (2018) Chitinase production by Trichoderma harzianum grown on a chitin-rich mushroom byproduct formulated medium. Waste Biomass Valor. https:// doi.org/10.1007/s12649-018-0328-4

Vos CM, De Cremer K, Cammue BP, De Coninck B (2015) The toolbox of Trichoderma spp. in the biocontrol of Botrytis cinerea disease. Mol Plant Pathol 16(4):400-412. https://doi.org/10.1111/mpp.12189

Xie BB, Li D, Shi WL, Qin QL, Wang XW, Rong JC, Sun CY, Huang F, Zhang XY, Dong XW, Chen XL, Zhou BC, Zhang YZ, Song XY (2015) Deep RNA sequencing reveals a high frequency of alternate splicing events in the fungus Trichoderma longibrachiatum. BMC Genomics 16(1):54. https://doi. org/10.1186/s12864-015-1251-8

Yang X, Cong H, Song J, Zhang J (2013) Heterologous expression of an aspartic protease gene from biocontrol fungus Trichoderma asperellum in Pichia pastoris. World J Microbiol Biotechnol 29(11):2087-2094. https://doi. org/10.1007/s11274-013-1373-6

\section{Publisher's Note}

Springer Nature remains neutral with regard to jurisdictional claims in published maps and institutional affiliations. 